Offshoring: Big Deal, or Business as Usual?

by

Alan S. Blinder

Princeton University

CEPS Working Paper No. 149

June 2007

Acknowledgements: This paper was presented at the Alvin Hansen Symposium at Harvard University, May 2, 2007. I would like to thank, without implicating, Gene Grossman and Helmut Wagner for helpful comments on an earlier draft, Lael Brainard and Alan Krueger for valuable references, and Princeton's Center for Economic Policy Studies for financial support. I am also grateful for many useful comments from colleagues on several earlier papers on this subject. 
President Bush is on an eight-day tour of Asia. He's visiting American jobs.

-- David Letterman in 2006

More things are tradable than were tradable in the past, and that's a good thing. -- Greg Mankiw in 2004

Economists set themselves too easy, too useless a task if in tempestuous seasons they can only tell us that when the storm is long past the ocean is flat again.

-- John Maynard Keynes in 1923

If there is a live intellectual debate over offshoring — which is, after all, the premise of this symposium--what is it all about? What separates those of us who worry about the effects of offshoring on the U.S. labor market from those who--like Greg Mankiw in 2004 and Jagdish Bhagwati today—see offshoring of services as just the latest expansion of international trade and, therefore, as "a good thing” for the United States-period ${ }^{1}$

\section{A definition}

Perhaps I should start with a definition because "offshoring” is often confused with "outsourcing," which is different. Specifically, a job is outsourced when it is contracted out of the company-presumably to another company. The country in which the job is now being done is irrelevant. So, for example, Citibank can outsource the backoffice operations of its U.S. credit card business to a company in South Dakota or to one in South Korea. In the latter case, the jobs are also offshored; in the former case, they are not. Offshoring, by contrast, means moving jobs out of the country, whether or not they leave the company. Thus, Microsoft offshores (but does not outsource) jobs when it

\footnotetext{
${ }^{1}$ There is no issue over whether or not offshoring is a positive development for the world as a whole. We all agree that it is.
} 
moves jobs from its software laboratory in Redmond, Washington to its laboratory in Cambridge, England. But if Microsoft hires another company to provide software lab services in the United States, those jobs are outsourced but not offshored. And, of course, if Microsoft contracts with Infosys to get the work done in Bangalore, the jobs are both outsourced and offshored. The National Academy of Public Administration (2006, p. 42) suggests defining offshoring as "U.S. firms shifting service and manufacturing activities abroad to unaffiliated firms or their own affiliates.” That seems a workable definition to me.

The offshoring phenomenon, which is about the location of work, does not correspond neatly any category of standard international trade data. Much U.S. service offshoring today counts as imports of services. But many U.S. service imports, e.g., tourist services consumed abroad, do not constitute offshoring because the people who do the work (in hotels, restaurants, etc.) deliver their services locally. Furthermore, some offshoring is classified as foreign direct investment (FDI), rather than as trade-Microsoft's building of a lab in England being a prime example.

Finally, I come to the most slippery part of the concept-the one that is nearly impossible to measure. In line with the above definition, we would like to say that a U.S. company offshores jobs when it creates new jobs to serve our market, but locates them overseas. So, for example, if a U.S. manufacturer expands production by opening a factory in China, for export back to the United States, we want to say that the jobs in that factory have been offshored—even though they never existed in the United States. Measuring this particular type of offshoring requires answering counterfactual 
questions-like “Would those jobs otherwise have been created in the U.S.?”--that will never be captured in official data.

\section{The debate}

With the definition now (hopefully!) clear, let me turn next to what the debate is not about. First, it definitely is not about the validity of the theory of comparative advantage. David Ricardo got that approximately right about two centuries ago, and I have little or nothing to add. Besides, I am not so foolish as to engage in a debate over the nuances of trade theory with the finest trade theorist of our age. Let me just state-as clearly and unequivocally as I can--that I am not claiming that the United States is about to lose comparative advantage in everything! Second, the debate is not even about the common presumption that every nation gains from trade, although that particular "theorem" does require an important footnote that I will mention shortly. Third, it is not about the comparative statics of how either social welfare or employment compares in one equilibrium state (say, after offshoring) versus another (say, before offshoring). I am willing to stipulate that, when all the dust has settled, the U.S. economy as a whole, though certainly not every American, is likely to be better off because of service offshoring. In particular, we worry-warts are not concerned that the U.S. faces a bleak future of mass secular unemployment. Thus I am happy to accept Bhagwati, Panagariya, and Srinivasan’s (2004, p. 94) assessment that offshoring “is fundamentally just a trade phenomenon; that is, subject to the usual theoretical caveats and practical responses, [it] leads to gains from trade, and its effects on jobs and wages are not qualitatively different from those of conventional trade in goods.” We will not argue about that. 
What, then, is the offshoring debate about? Leaving aside the lunatic fringes (each side can name its own favorite lunatics), I believe it is about whether the offshoring of service jobs from rich countries like the United States to poor ones like India is likely to be a big deal, something I have compared to a new industrial revolution (Blinder, 2006a), or simply more business as usual-yet another routine expansion of international trade, as Bhagwati, Panagariya, and Srinivasan (2004) say. Count me as firmly in the first camp. Which makes me a worry-wart because I believe that the confluence of rapid improvements in information and communications technology (ICT) coupled with the entry of giants like China and India into the global economy is creating a situation which, while perhaps not theoretically novel, may be historically unprecedented. When I say it will be a "big deal,” I mean that offshoring will force major changes in the U.S. industrial structure, in what Americans do to earn their livings, probably in wages, almost certainly in job security and turnover, and so on. As I noted in my Foreign Affairs essay last year (Blinder, 2006a, p. 113), "Sometimes a quantitative change is so large that it brings about qualitative changes.” I suspect service offshoring will be like that.

In thinking through the consequences of the confluence of ICT breakthroughs and vast new pools of labor, it is crucial to keep in mind a distinction I emphasized in Blinder (2006a) between personally-delivered services and impersonally-delivered services. Impersonal services are the ones that can be delivered electronically from afar with little or no degradation of quality—either now or sometime in the future when the technology has improved (e.g., keyboard data entry, manuscript editing). They are therefore either actually or prospectively tradable and thus potentially offshorable. Personal services, by contrast, are the ones that either cannot be delivered electronically (e.g., child care) or 
that suffer severe degradation of quality when so delivered (e.g., surgery). They are therefore, for all practical purposes, non-tradable. ${ }^{2}$

We may be standing, right now, at an historical cusp. Looking backward, the crucial labor market divide has been the familiar one: between jobs that require high levels of education and jobs that do not. Roughly speaking, highly-educated workers have fared far better than poorly-educated ones for a generation. But looking forward, the more critical distinction may be the unconventional divide between personal and impersonal service jobs. And the interesting thing is that these two divisions of the workforce are almost completely unrelated. A few examples will illustrate what I mean.

It seems to me unlikely that the services of either taxi drivers or brain surgeons will ever be delivered electronically by long distance. The first is a "bad job" with negligible educational requirements; the second is just the reverse. On the other hand, typing services (a low-skill job) and security analysis (a high-skill job) are already being delivered electronically from India--albeit on a small scale so far. Most physicians need not fear that their jobs will be moved offshore, but perhaps radiologists should. ${ }^{3}$ The work of policemen will not be replaced by electronic delivery, but the work of security guards who monitor sites by television might be. I could go on and on with examples like these.

Briefly stated—and this is something to which I will return--the reasons why I see service offshoring as a large and potentially disruptive force for the United States (and for

\footnotetext{
${ }^{2}$ Or so we think. Since it requires the gardener to be physically present, lawn care appears to be a quintessentially personal service. But a Chinese-American businessman recently told me about a company that is developing technology to operate a lawn mower electronically from China!

${ }^{3}$ Levy and Yu (2006) show that offshoring of radiological services is severely restricted by regulation. So large-scale offshoring in this domain would require regulatory changes. Technology is not the limiting factor.
} 
other rich countries) are that (a) so many Americans now earn their living providing services, ${ }^{4}$ (b) the range of services that can be delivered electronically is sure to expand as the technology improves, and (c) the number of Indian, Chinese, and other workers who are capable of providing those services will only grow over time-perhaps explosively. Does anyone disagree with any of those three propositions?

That said, no one can predict the future. So why bother to debate now whether service offshoring will eventually turn out to be business as usual or a big deal? Why not just wait and see? My answer is simple: The answer matters for public policy. If this new wave of international trade constitutes no more than business as usual, then the appropriate policy response is approximately nothing. With only minor assists, laissez faire will fare just fine; the main trick is to avoid protectionism. But if offshoring will eventually amount to something approaching a new industrial revolution, then a variety of policy responses may be called for.

I will return to policy responses at the end. First let me frame the intellectual debate--just to establish that we worry-warts are not all muddled thinkers. ${ }^{5}$

\section{Some self-evident truths}

Since Adam Smith and Thomas Jefferson published their best work at exactly the same time, let me begin the debate by holding a few truths to be self evident.

First, as just mentioned, we worriers do not question either the validity or the importance of the theory of comparative advantage. Nor do we doubt the advisability of exploiting a country’s comparative advantages rather than flailing out against those of

\footnotetext{
${ }^{4}$ According to the BLS's payroll survey, 83.4\% of U.S. jobs in 2006 were producing services—if we count all government jobs as service jobs.

${ }^{5}$ Bhagwati et al. entitled their 2004 paper, “The Muddles over Outsourcing.” (They meant offshoring.)
} 
other countries. I yield to no one in my defense of free trade. ${ }^{6}$ And nothing said herein should be construed as favoring protectionism in any way.

Second, I understand that trade is a two-way street. The eventual post-offshoring equilibrium cannot have the United States producing only nontradables and exporting nothing. Precisely what we will export then is a good question, for our trade patterns may have to change substantially. (More on that later.) And we need not have balanced trade in goods and services because the U.S. will surely continue to export financial assets for a long time. But America must and will remain a great exporting nation as well as a great importing nation. After all, market-driven trade patterns depend on comparative advantages, not absolute advantages.

Third, comparative advantage in the modern world has relatively little to do with natural resource endowments. David Ricardo understood well why Portugal, not England, grew the grapes. These are basically the same reasons why, even today, Brazil exports bananas and Saudi Arabia exports oil. But for most of modern trade, we can mostly ignore natural endowments. Silicon Valley did not become what it is today because of a natural abundance of silicon. Nor did the U.S. develop a strong comparative advantage in aircraft because our air provides more lift. When it comes to trade in services (and much else), the skills of a country’s workforce matter much more than its climate, soil, or natural resources. It follows from this obvious insight that, in an important sense, comparative advantage is made not born. A determined and successful country can create comparative advantage for itself in industries and/or tasks where it formerly had noneas, for example, Japan did so brilliantly in automobiles and electronics. Thus, as

\footnotetext{
${ }^{6}$ In fact, ever since my stint in government in the 1990s, many people have heard me say that my personal views on trade policy are somewhat to the right of Jagdish Bhagwati!
} 
Bhagwati (1997) has aptly put it, modern comparative advantage (as opposed to resourcebased comparative advantage) may be "kaleidoscopic," meaning that it can move around from one country to another in response to changes in costs.

Fourth, I come to the footnote mentioned earlier. Trade theorists have long understood that it is theoretically possible for a country to end up worse off when a "new entrant" country comes along and takes away its comparative advantage in one or more important industries. ${ }^{7}$ Indeed, comparative advantage does not have to be lost. As Hymans and Stafford (1995) show, the home country can become worse off if the foreign country merely gets better at producing the good that is (and remains) the home country's comparative advantage. In the offshoring context, think about India either taking away or shrinking the United States' former comparative advantages in a number of service occupations. ${ }^{8}$ Of course, even if lost or fading comparative advantage is the problem, protectionism is not the solution. In fact, it will probably only cause further damagewhich takes us back to my first self-evident truth. However, loss of comparative advantage in major industries and occupations is a serious cause for concern in the future; and we worry-warts are worried about it.

Fifth, and finally, it cannot be emphasized enough that the debate about the "threat" from offshoring is not about the nature of the eventual equilibrium position. For example, we big-dealers do not believe that the offshoring of millions of service jobs will lead to mass unemployment in the United States. However, we do foresee a massive transition as millions of workers are rudely reallocated by the market mechanism. Unfortunately, the vast majority of trade theory pertains to the analysis of full-

\footnotetext{
${ }^{7}$ See Bhagwati (1968), Gomory and Baumol (2000), Samuelson (2004).

${ }^{8}$ This is a prospective possibility. It recent years, the U.S. terms of trade have improved, not deteriorated.
} 
employment equilibrium states and has little or nothing to say about either unemployment or transitions. ${ }^{9}$ Too often, economists simply label certain things as "transition costs” and then proceed to ignore them. But when it comes to a phenomenon as big as service offshoring, such a cavalier treatment strikes me as more than a trifle hypermetropic. ${ }^{10}$ In addition to job losses, it is quite likely that, by stripping away their previous immunity to foreign competition, offshoring will depress the real wages of many service workers in the U.S. who do not lose their jobs.

\section{Now, about that transition...}

So both my intellectual focus and my practical concerns center on the transition, not on the ultimate equilibrium state. Let us therefore pose, and attempt to answer, a series of questions, both qualitative and quantitative, about the likely nature of this transition. Here, the "truths" become less than self-evident because we are speculating about the future.

I start with the hypothesis that offshoring will usher in a massive and disruptive transition—a new industrial revolution, if you will. Past industrial revolutions have changed the faces of societies, causing great dislocation before ultimately leaving those societies much better off. I expect this one to follow that same pattern. But before we reach the promised land, I suspect that we Americans will experience a nasty transition, lasting for decades, in which not just millions but tens of millions of jobs are lost to offshoring. (That's gross, not net, losses of course.) Which brings to mind the quotation

\footnotetext{
${ }^{9}$ See, for example, Davidson and Matusz (2000), who criticize standard trade theory for this reason.

${ }^{10}$ Hypermetromia is the opposite of myopia.
} 
from Keynes at the start of this paper. I want us to think about the tempestuous season, not just the eventually flat ocean.

Now, tens of millions of jobs is vastly more offshoring than has occurred to date. While estimates are fragmentary, it seems a good bet that offshoring to date has cost fewer than a million American service jobs, maybe a lot fewer. ${ }^{11}$ But I suggested in Blinder (2006a) that the job losses experienced to date are probably just the tip of a much larger iceberg whose contours will only be revealed in time. Why do I say this?

Since we have no crystal ball, let’s do a thought experiment. Start with a stylized multi-country, static equilibrium model of international trade with a wide variety of goods and services. $\mathrm{N}$ countries, $\mathrm{M}$ goods, and L factors of production (e.g., different types of labor), if you like to talk that way. There is full employment everywhere. (Isn’t there always, in trade models?) The $\mathrm{N}$ countries vary greatly in their stage of development, the skill mixes of their workforces, and their patterns of comparative advantage and disadvantage. The gains from trade in the M goods are therefore bountiful, and free trade will realize many of them. Now let’s perturb this Panglossian equilibrium with two big shocks.

First, add three large but poor nations to the world economy. Of course, I do not mean that three "new" countries literally rise like Atlantis from the sea. Think of them as having been disengaged from the global economy and then joining it in a big way. My empirical counterparts are, of course, China, India, and the former Soviet bloc. These three new countries bring a huge amount of additional labor into the global economy, some of it highly skilled. But they bring in comparatively little new capital. World factor

\footnotetext{
${ }^{11}$ See, for example, the summary of estimates in National Academy of Public Administration (2006), Chapter 4. Job losses in manufacturing, which started years earlier, have been much larger.
} 
proportions therefore shift substantially against labor. Suppose further that one of these new nations, call it "India," has millions of workers who speak fluent English--the language of the biggest, richest economy, which I will call "the United States.” These workers in India are thus able to provide U.S. firms with many services that require facility in English. We might say that, among poor countries, India has a comparative advantage in the electronic delivery of impersonal services in English.

What happens in the model? The first thing most economists would think of is a change in relative factor prices, perhaps a dramatic one. There should be downward pressure on the general level of real wages around the world. The impact should be especially large on the wages of highly tradable types of labor in the rich countries, especially where a lot of specific human capital is involved. Correspondingly, there should be upward pressure on the returns to capital. Looking around the world today, that all sounds pretty realistic. As Richard Freeman (2005, p. 3) has put it: "The entry of China, India and the former Soviet bloc to the global capitalist economy is a turning point in economic history" which will pose "a long and difficult transition for workers throughout the world."

Now bring in the second shock, which is technological. Suppose rapid improvements in ICT greatly expand the range of services that can be traded. One consequence is that many jobs that were formerly considered non-tradable become at least potentially tradable. (Some examples are accountants, security analysts, and radiologists.) Comparative advantage is up for grabs in these newly-tradable services-after all, there was no trade in them before. More than likely, such comparative advantage will be made not born. And the patterns of trade that emerge are unlikely to be resource- 
based to any important extent--unless you classify workforce skills and speaking English as resources. Thus, in particular, India may prove to have a strong comparative advantage in a range of newly-tradable services that require English language skills. And the workers who hold those same jobs in the United States will find that their jobs are suddenly “in play”--which will put even more downward pressure on their wages. It is not a pretty picture for American call center operators or computer programmers.

Now add one more worrisome factor to the mix: the cost disease of the personal services, also known as Baumol's disease. ${ }^{12}$ Baumol's disease, you will recall, is the idea that the prices of personal services, in which there is little scope for productivity improvement, are destined to rise relative to the prices of either manufactured goods (Baumol's central example) or impersonal services (my corollary here), which do experience regular productivity gains. It explains, for example, why the relative prices of live performances, college education, mail delivery, and health care services all have risen sharply over the decades. ${ }^{13}$

Ever-rising relative prices have predictable consequences because demand curves slope downward. Specifically, Baumol’s disease predicts decreasing relative demands for personal services and increasing relative demands for goods and impersonal services— unless differential income elasticities overwhelm the relative price effects. ${ }^{14}$ Here Baumol's disease connects to the offshoring problem in a rather disconcerting way. I have argued that changing trade patterns will keep almost all personal service jobs at home while a large number of jobs producing goods and impersonal services will migrate

\footnotetext{
${ }^{12}$ Among many references that could be cited, see Baumol (1967).

${ }^{13}$ Nordhaus (2006) offers extensive empirical support for these and other predictions of Baumol's disease.

${ }^{14}$ Robert Lawrence (this volume- - see below) suggests that many of the most important personal services, such as health care and education, do in fact have high income elasticities. More on this later.
} 
overseas. When you add to that the likelihood that demands for many of these costly personal services may shrink relative to the demands for ever-cheaper manufactured goods and impersonal services, you realize that the rich countries may have some major readjustments ahead of them.

But, of course, all is not negative. The entry of the three large-but-poor countries into the global economy broadens markets and creates expanded opportunities not only for U.S. capital, but also for certain types of U.S. labor--including some service labor. The U.S. will “onshoring” as well as offshoring. So, for example, it may be a very good time to be an American investment banker or movie star. Furthermore, the cost reductions achieved by the industries that reap large gains from offshoring are analogous to productivity improvements in the U.S.--which, other things equal, will raise the demands for both labor and capital in those industries. ${ }^{15}$ These and other favorable adjustments are also part of the transition.

That said, I can't help believing — and this is what makes me a worry-wart rather than a relaxed, business-as-usual guy — that the gross job losses in the rich, Englishspeaking countries will (a) continue for decades, (b) eventually be huge, (c) pose a variety of difficult adjustment problems, and (d) dominate the political economy landscape for years. Let me take up each of these four claims one at a time, turning as I do so from abstract trade theory to what may become the new practical realities for the United States. Remember, my assigned task is not to overturn received trade theory, but only to defend the "big deal” hypothesis.

\footnotetext{
${ }^{15}$ As emphasized by Grossman and Rossi-Hansberg (2006).
} 


\section{Will offshoring continue for decades?}

Actually, I'd like first to hold one more truth to be self-evident: that the two big, historic forces driving the offshoring phenomenon are going to be with us for some time.

The rate of technological change in ICT may accelerate or decelerate from its recent dizzying pace. I do not know. Nor do I know in which novel directions future developments will take us. But I am confident that ICT will keep on improving inexorably, thereby steadily increasing the range and complexity of the services that can be delivered electronically, and the quality of that delivery. Does anyone seriously doubt that network connections, voice recognition systems, the quality of video conferencing, artificial intelligence, and the like will all be much better and cheaper a generation from now than they are today?

Thus I was dumbstruck when one of my critics claimed that my rough estimates of offshorability in Blinder (2006a) are far too high because: "Most jobs at risk of offshoring today or in the near future are likely to be at risk in twenty years, while jobs not at risk today are likely to not be at risk in the future (emphasis added)" (Atkinson, 2006, p. 3). Read those italicized words again. They remind me of the apocryphal story of the commissioner of the U.S. Patent Office who allegedly urged President McKinley to abolish the office because "everything that can be invented has already been invented.” I claim no clairvoyance. But it is a virtual certainty that an increasing array of services will become offshorable over time- that is, many jobs that are not now at risk will be at risk in the future.

Here's an example I like to use with audiences like this one. Think about a highlyskilled, well-paid occupation with which we are all familiar: teaching economics in a 
university. Now here's my question. Twenty or thirty years from now, will Economics 101 lectures at Princeton be delivered by a life-like hologram of a well-educated and well-spoken professor who is actually in Mumbai, but who can see and hear the Princeton students via video and audio hookups — and who earns one-fifth of what I do? ${ }^{16}$ Actually, I think the answer to the question for Princeton and Harvard is probably no. Our massive endowments will allow us the luxury of maintaining the more expensive personal treatment for longer. But what about the $99.9 \%$ of colleges and universities that are not as well-endowed and that will be under unremitting cost pressures from Baumol's disease? It is at least conceivable to me that this eminently personal service will one day become an impersonal service. Every reader can surely think of other examples. In imagining what might be possible by 2037, try to remember how much things have changed since 1977.

The second major driver of offshoring is the emergence of India, China, and other countries. It seems a good bet that these countries will continue to provide not just large but increasing numbers of skilled workers to the world economy for at least a generation. It takes time to train your labor force, even when your economy is growing at $10 \%$ per year. Thus I have no quarrel at all with Bhagwati, Panagariya, and Srinivasan’s (2004, p. 108) observation that: “The notion that India and China will quickly educate 300 million of their citizens to acquire [the] sophisticated and complex skills at stake borders on the ludicrous... Adding 300 million to the pool of the skilled workers in India and China will take some decades.” Read that last sentence again. Two to three decades seems to be about the right time frame for thinking about service offshoring, and 300 million is

\footnotetext{
${ }^{16}$ One economist to whom I posed this question suggested that, by then, the students "in the seats" might also be holograms! Of course, the U.S. might also "onshore" some college teaching services if foreign students tune in to our lectures.
} 
roughly equal to the present workforces of the United States and Western Europe combined! As I say: It’s a big deal.

\section{Will offshoring eventually be huge?}

How large will the (gross, not net) job losses eventually be? No one knows, of course. Bhagwati, Panagariya, and Srinivasan meant to minimize the perceived threat to U.S. workers when they wrote the words just quoted. But most American workers won't find them very reassuring. Of course, only a fraction of those hypothetical 300 million new workers will compete for what we now think of as American jobs. But even if only, say, one-fifth of them do so, 60 million is more than enough to create something akin to a new industrial revolution.

In a current working paper (Blinder, 2007), I make some educated guesses about how many U.S. jobs are or will be potentially offshorable. My intent there is to guesstimate the outer limits of potential offshoring, not the likely amount of actual offshoring (which is unknowable). Just as there are still steelworkers and textile workers in American manufacturing plants, despite decades of offshoring in these industries, so will there still be American workers doing impersonal service jobs in the U.S. a generation from now. Here, in a nutshell, is how I made my guesstimate. (And, by the way, I welcome both other estimates and suggestions for improvement.)

I began with the premise that the right way to think about offshorability is to study the characteristics of jobs (e.g., do they require personal contact?), not the characteristics of workers (e.g., how many years of education to they have?). So I gathered data on the approximately 800 occupations in the Bureau of Labor Statistics’ 
six-digit Standard Occupational Classification (SOC). For virtually all of these, the O*NET, an online service developed for the BLS as a replacement for the old Dictionary of Occupational Titles (DOT), offers a wealth of descriptive information about the occupation, including the main work activities that characterize the job. After giving up on using these data to create an objective ranking of the 800 occupations by their degree of offshorability, ${ }^{17}$ I used $\mathrm{O} *$ NET data to create a subjective ranking running from 100 (the most offshorable jobs) down to zero (the least offshorable).

In developing those rankings, I leaned heavily on two critical determinants of offshorability. The first has been emphasized already: Can the work be delivered to a remote location—which, for services, generally means electronic transmission? And if so, how severely is the quality degraded? Using information in the job descriptions provided in the $\mathrm{O}$ NET, I rated each occupation on this criteria subjectively. For example the importance of personal, face-to-face contact was used as a strong negative indicator of offshorability. The second criterion is even more obvious, and it is at least closer to being objective: Must the job be performed at a specific U.S. location? So, for example, data entry, telemarketing, and computer programming were rated as highly offshorable (index numbers at or near 100), while nursing, judging or arguing cases in court, and working in a day care center were rated as impossible to offshore (index numbers at or near zero). Using these and other criteria, I assigned a number between 0 and 100 to each occupation, indicating its potential offshorability. Those numbers were then used to create the histogram reproduced below as Figure 1.

\footnotetext{
${ }^{17}$ For an explanation of how I tried to do this, and why it failed, see Blinder (2007, Section 5.)
} 


\section{Figure 1}

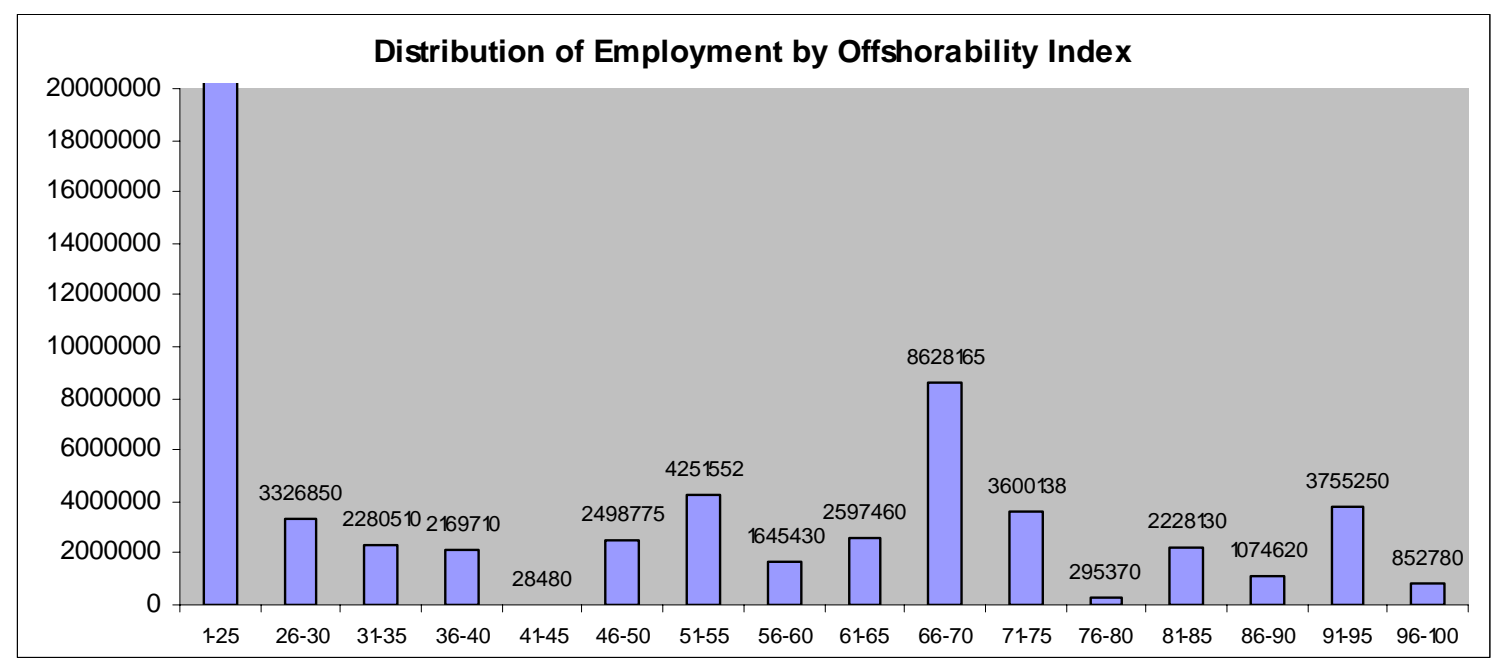

Source: Blinder (2007).

From this histogram, deriving an estimate of the number of jobs that are potentially offshorable is a simple matter of counting down from the righthand tail--once you decide where to place the dividing line between jobs that are and are not offshorable. ${ }^{18}$ I drew that line in three different places, thereby creating three estimates of the fraction of jobs that are potentially offshorable - which I would characterize as conservative (22.2\%), moderate (25.6\%), and aggressive (29.0\%). Based on today’s workforce, that range corresponds to about 30-40 million jobs—a big number. While the range is wide in absolute size, it is narrow in the relevant policy sense: The policy implications do not hinge on whether the correct number is closer to 30 million or to 40 million.

\footnotetext{
${ }^{18}$ The pronounced spike in the 66-70 range reflects my arbitrary decision to place the majority of manufacturing jobs there. It is of no importance because all candidate dividing lines fall to the left of it. (Manufacturing jobs are considered potentially offshorable.) Similarly, the huge pile-up in the 1-25 range reflects my decision not to bother ranking jobs that are clearly not offshorable. Thus, for example, I made no effort to decide which of these jobs was a " 1 " and which was a " 24 " because the dividing line would never be drawn that low.
} 


\section{Major adjustment problems?}

I am not—repeat, not—claiming that 30-40 million Americans will lose their jobs because of offshoring. Rather, this is my rough estimate of the number of jobs that will face potential foreign competition. Only a fraction of them will actually be moved offshore. In addition, this transition will take some time-perhaps decades. Slower transitions are easier to handle than faster ones. Furthermore, there will also be some onshoring, as American businesses export new and expanded services to the rest of the world. As I suggested earlier, if you compare the original pre-offshoring equilibrium to the eventual post-offshoring equilibrium once the adjustment is complete, a reasonable estimate of the likely net job loss is zero. But gross job losses will be huge, leading to a great deal of churning, much displacement (and re-employment) of labor, and many difficult adjustments—occupational, geographical, and in other respects.

Let's start with employment. Here, my main (and obvious) point was anticipated by Bhagwati (1997, p. 22), who noted that "the changed external environment of a kaleidoscopic comparative advantage” leads to “increased job insecurity... directly by increasing job displacements.” Furthermore, he added, this “phenomenon is a definite and enduring change.” I agree.

To a macroeconomist, it is natural to subdivide the job displacement that offshoring might cause into three components. First, more job churn probably raises the equilibrium or natural rate of unemployment, ${ }^{19}$ though perhaps not by very much owing to the huge job churn that is normal for the U.S. labor market. Second, the changes wrought by offshoring will probably lead to substantial "structural” unemployment due to

\footnotetext{
${ }^{19}$ Davidson and Matusz (2006) chide trade theorists for ignoring this obvious fact. They suggest that omitting job churn leads to highly misleading conclusions in trade models.
} 
occupational/skill mismatch. And third, there may well be substantial amounts of “Keynesian” unemployment due to deficient demand during the transition years. A brief word on each: ${ }^{20}$

First, frictional unemployment from job churn: When the gross job destruction rate rises, the pool of unemployed workers also rises unless the gross job creation rate rises parri passu. My belief-and only time will tell whether this is correct-is that offshoring per se will lead to far more job destruction than job creation in the United States, ${ }^{21}$ and to just the opposite in India and China. If so, the "full employment" unemployment rate will rise. Any good macroeconomist will point out that this rise in the natural rate of unemployment should be transitory. But the transition period could last for years.

Next comes structural unemployment from mismatch. The heart of my argument is that, over a period of decades, many millions of Americans may find themselves displaced from their previous jobs in impersonal service occupations and forced to find work elsewhere. Open, flexible labor markets do a remarkably good job of handling large-scale reallocations like that. After all, more than four million American workers either lose or gain a job (or both) each month. But the adjustment will be neither painless nor immediate-after all, changing occupations is a lot harder than changing jobs. In the interim, structural unemployment will rise.

Finally, there is Keynesian unemployment from deficient aggregate demand. Job losses from offshoring arise when the demand for certain services shifts from the United

\footnotetext{
${ }^{20}$ Offshoring is, of course, not the only reason, nor even the main reason, for any of these three types of unemployment

${ }^{21}$ Of course, other phenomena-like invention and innovation-will produce more job creation than destruction.
} 
States to other countries. When that happens, U.S. imports rise, shifting the trade balance in the negative direction and reducing aggregate demand. In a Keynesian world--and that, after all, is the world in which we live-deficient demand leads to higher (cyclical) unemployment. Once again, any competent macroeconomist will point out that this extra bit of unemployment is transitory. But most of us feel that the proper time frame for thinking about “transitory” Keynesian unemployment is a year or two, not a month or two.

Now turn from jobs to wages. Even where jobs are simply rendered offshorable, rather than actually moved offshore, the threat of potential offshoring would be expected to create downward pressure on real wages. Might this be happening already? My priors told me no; wage loss from offshoring is something to worry about in the future, not now. But a simple wage regression for 2004 run using the constructed data on offshorability mentioned above says otherwise. Specifically, in Blinder (2007) I ran the following conventional log wage equation across 291 occupations: $^{22}$

$$
\ln (\mathrm{w})=\text { const. }+0.152 \mathrm{ED}-0.138 \mathrm{D}_{86-100}-0.118 \mathrm{D}_{76-85}+\text { other dummies }
$$

where t-ratios are in parentheses, $\mathrm{w}$ is the median wage in the occupation, ED is (approximately) average years of education, $\mathrm{D}_{86-100}$ is a dummy variable equal to one for occupations with offshoring scores between 86 and 100 (the most offshorable occupations), $\mathrm{D}_{76-85}$ is a corresponding dummy for occupations with offshoring scores between 76 and 85, and none of the other six offshoring dummies come close to statistical significance. Taken at face value, this regression says that workers in the most offshorable jobs were already paying an estimated 13\% wage penalty in 2004, given their

\footnotetext{
${ }^{22}$ See Blinder (2007) for why $n=291$ in this regression. I have no measure of average years of experience by occupation.
} 
educational attainment. ${ }^{23}$ This is a surprising —and, to me, provocative—finding. It is hard to imagine that the mere threat of offshoring was having such large effects on wages by 2004. Nevertheless, the empirical fact remains: Controlling for education, wages in the most offshorable jobs were unusually low.

Furthermore, the transition costs caused by the adjustment to offshoring will not be limited to those I have just discussed: a "transitory" rise in unemployment (that could last many years) and potentially permanent declines in real wages for workers in highlyoffshorable occupations. There will also be sizable adjustment costs if tens of millions of American workers must change occupations, move geographically, or both. Capital, which is not $100 \%$ malleable, will also have to be redeployed.

\section{A big political issue?}

As we all know, free trade is under attack in the United States (and elsewhere) today, even though the unemployment rate has been hovering around $4.5 \%$ and offshoring has cost few American jobs to date. We are left to imagine what might happen to public support for free trade if, say, 10 million more jobs were offshored, wages were further depressed, and job market churn, mismatch, and Keynesian unemployment combined to raise the unemployment rate.

Protectionism will not be an effective remedy for any of these problems. While goods arriving on ships can perhaps be kept out of the United States by the Coast Guard, electronically-delivered services arriving via wireless transmission cannot be. But the fact that protectionism will not work does not mean that it will not be tried. In fact, I fear that

\footnotetext{
${ }^{23}$ In case you are thinking otherwise, ED and the offshoring dummies are nearly orthogonal.
} 
large-scale offshoring will seriously undermine public support for the open trading system in the U.S. and other rich countries. In this context, four things are worth noting.

First, and without repeating arguments I have already made, I believe the adjustment to offshoring will be of major magnitude, will last a long time, and will create millions of losers. Those are the precisely the ingredients needed to create a big political issue- even before you throw in the demagoguery.

Second, service offshoring is exposing an entirely new class of people to the joys of competition from cheap foreign labor. Factory workers in rich countries have come to understand, sometimes through bitter experience, that people in emerging-market countries can do their jobs pretty well--and at a fraction of their wages. While these manufacturing workers do not relish foreign competition, they have come to see it as one of the hazards of modern industrial life—like bankruptcies and recessions. But whitecollar professionals have not. American computer programmers have already felt the sting of offshoring. But as of now, accountants, lawyers, editors, radiologists and the like really have not. So this will be a new experience for them, and it is predictable that they will not like it. What's more, these professionals are, on average, better educated, more vocal and articulate, and probably more politically engaged than the blue-collar workers who have been dealing with offshoring for decades. So this new class of trade victims could well prove to be a potent political force. Maintaining free trade in this environment will be a challenge.

Third, both the adjustment costs and the ultimate gains from trade will be larger for the United States and other English-speaking countries than for other rich countries that do not speak English because the English speakers can and will make more use of 
electronically-delivered services. India (and, to a lesser extent, the Philippines) will continue to exploit their linguistic comparative advantage by providing the U.S. with a huge pool of skilled and semi-skilled service labor that is proficient in English. By contrast, it is impossible to find comparably large pools of potential service workers in poor countries who are proficient in, say, Japanese or German. So service offshoring probably poses much larger transition problems for the U.S. than for either continental Europe or Japan. ${ }^{24}$

Fourth, the United States has always done a woefully inadequate job of what economists call "compensating losers.” It has been known since the beginning of trade theory that changes in international trade create both winners and losers. The basic gainsfrom-trade "theorem" is that the gains to the winners exceed the losses to the losers, leaving the nation as a whole ahead. ${ }^{25}$ That's nice to know, and it is the main reason why almost all economists support free trade. But trade liberalization is not, repeat not, a Pareto improvement unless the losers are actually, not theoretically, compensatedwhich they never are.

For all these reasons, my crystal ball tells me that offshoring may be the biggest political issue in economics over the next generation.

\section{Policy I: Building a better safety net}

What, then, can policymakers do to make the transition faster and/or less painful-which might help defuse protectionist sentiment and help preserve the liberal trading system? My responses fall into three baskets.

\footnotetext{
${ }^{24}$ Chinese-speaking Singapore and Taiwan may have an even bigger adjustment to make. But they are small countries.

${ }^{25}$ As I noted earlier, this is not really a theorem. There are cases where the losses exceed the gains.
} 
The first picks up on the observation I just made: While we have had one form or another of trade adjustment assistance (TAA) in the United States since the early 1960s, our track record with it is, in a word, miserable. With some exceptions, TAA is not very generous; it has been criticized for providing more assistance than adjustment; and the number of people actually served by TAA programs is pretty small. For example, during fiscal year 2006, the U.S. Department of Labor reported about 53,500 new cases of financial assistance and about 36,000 new cases of job training under TAA.

One reason for these shortcomings is that TAA has never been a high priority for our national government--an attitude that may change as increasing numbers of Americans come to need it. But a second reason is that TAA programs have neither been particularly well-designed nor well-advertised to date. ${ }^{26}$ We simply must find ways to provide TAA better than we have in the past. For openers, we need to cover service workers.

That said, it is often difficult to know which displaced workers lose their jobs to trade competition (and therefore qualify for TAA) and which lose their jobs for other reasons. Nor is it always sensible to try to figure it out. Why, for example, should workers displaced by trade be treated better than workers displaced by technology? Posing that question suggests that policymakers should perhaps concentrate on repairing and extending the social safety net for all displaced workers. Better unemployment insurance, a more generous Earned Income Tax Credit, universal health insurance, greater portability of pensions, and new ideas like wage-loss insurance would cushion the

\footnotetext{
${ }^{26}$ As an example of the latter, the Trade Adjustment Assistance and Reform Act of 2002 created a small wage-loss insurance program for workers above a certain age who lose their jobs to import competition or offshoring. But so far, it has been taken up by fewer than 7,000 workers.
} 
blow for workers who lose their jobs. All this should be uncontroversial. But, apparently, it is not.

Beyond that, the U.S. government must find ways to transform our inadequate social safety net into an effective social trampoline that bounces displaced workers back into productive employment--thereby helping the nation return to Lyndon Johnson's original Great Society concept: “a hand up, not a handout.” According to the conventional wisdom, federal job training programs have a dismal track record. But in fact, their estimated rates of return have been quite respectable. The real problem is that, whether measured by the number of dollars spent or by the number of people served, we have never tried very hard. In evaluating these programs some years ago, LaLonde (1995, p. 149) concluded that “...we got what we paid for. Public sector investments in training are exceedingly modest compared to [the problems they] are trying to address.” And recent years have seen cutbacks. We simply must do better in the future.

\section{Policy II: Preparing the workforce of the future ${ }^{27}$}

Ever since the late 1970s, the demand for labor appears to have been shifting away from high school graduates and dropouts and toward college graduates. This shift, most economists believe, is the primary (though not the sole) reason for rising income inequality—dwarfing, for example, any effects of trade. ${ }^{28}$ Economists have given this phenomenon an antiseptic name: skill-biased technical progress. It means that the labor market has turned ferociously against those with little education and low skills.

\footnotetext{
${ }^{27}$ This section borrows heavily from Blinder (2006b)

${ }^{28}$ See, for example, Burtless (1995).
} 
So far, America's response to this problem has not been to strengthen the social safety net, but concentrate instead on keeping more young people in school longer (e.g., reducing high school dropouts and sending more kids to college) and improving the quality of schooling (e.g., via charter schools and No Child Left Behind). Success in these domains may have been modest, but it's not for lack of trying. Americans don't need to be reminded that education is important; the idea is etched into the public consciousness. Indeed, many people view education as the silver bullet. On hearing the question, "How do we best prepare the American workforce of the future?,” many Americans react reflexively with: "Send more kids to college, and get more of them to study science and math.”

Looking back over the past 30 years, that was probably excellent advice. But looking forward over the next 30 years, I suspect that more subtle educational advice will be needed. "Prepare our kids for the high-end personal service occupations that will not be offshored" is a more nuanced message than "keep them in school longer." But it may be more useful going forward. However, heeding that advice may require rethinking many aspects of our K-12 educational system in light of the new but critical distinction between personal and impersonal service jobs. As the first industrial revolution took hold, America radically transformed its educational system to meet the new demands of an industrial society. We may need to do something like that again.

In particular, I have argued that many impersonal service jobs will migrate offshore while personal service jobs will remain here. And it so happens that many wellpaid jobs providing personal services—such as carpenters, electricians, and plumbers--do not require a college education. Others, like doctors, of course do. Overall, there is 
probably little or no correlation between the educational requirements of a job and its degree of offshorability. ${ }^{29}$

But before going even one sentence further, let me state categorically that I do not deny that raising the average educational attainment of the U.S. workforce is advisable ceteris paribus. On the contrary, to the extent that education raises productivity and that better-educated workers are more adaptable and/or more creative, educational investments should continue to pay off handsomely. In addition, inventiveness probably stands on a foundation of education-Bill Gates' famous decision to drop out of Harvard notwithstanding. So it probably still makes sense to send more of America's youth to college. But over the next generation, what kind of education our young people receive may prove to be at least as important as how much. In that sense, a college degree may no longer be a panacea.

If this is so, what can we do about it? How can we prepare the workforce of the future for the brave new world of service offshoring — in which jobs in personal services grow relatively more abundant while jobs in impersonal services grow relatively more scarce? I am no educational expert, but let me offer a few ideas.

Starting in the elementary schools, we need to focus on developing our youngsters’ imaginations, problem-solving skills, and people skills (including, importantly, group learning) as much as their "reading, writing, and 'rithmetic.” Remember that grade you got on your kindergarten report card for "works and plays well with others”? It may become increasingly important as labor demand shifts toward personally-delivered services. Such training probably needs to be continued and made more sophisticated in the secondary schools, where, for example, good communications

\footnotetext{
${ }^{29}$ For empirical evidence supporting this point, see Blinder (2007).
} 
skills-both written and verbal-- need to be fostered. As one concrete example, it strikes me that the central thrust of No Child Left Behind is pushing American education in precisely the wrong direction. I am all for accountability. But the nation's school system will not build the creative, flexible, people-oriented workforce we will need in the future by force-feeding our kids rote preparation for standardized tests in the vain hope that they will perform as well as memory chips. They won't.

More vocational education is probably also in order. After all, nurses, carpenters, and plumbers are already scarce, and we will likely need relatively more of them in the future. Lately, I've been posing the following question to people: “Twenty-five years from now, who do you think will earn more: the average computer programmer or the average carpenter?” You might be amazed how many people guess carpenter-which is also my guess. Much vocational training now takes place in community colleges; so they, too, will need to adapt their curricula to the job market of the future. For example, they may need to turn out fewer computer programmers and more computer repairers. (The Geek Squad has a great future!)

While it is probably still true that we should send more kids to college and get more of them studying science, math, and engineering, we also need to focus on training more college and graduate students for the high-end jobs that are unlikely to move offshore, and on developing a creative workforce that will keep America incubating and developing new processes, new products, and entirely new industries. Offshoring is, after all, mostly about following and copying. American must lead and innovate instead--just as we have done in the past. That remark leads me straight to the third, and final, basket. 


\section{Policy III: Climbing the comparative advantage ladder}

When I speak about offshoring, one straightforward but difficult question often comes up. "You claim that, in the future, we'll be importing many services that we now produce at home. But if imports grow rapidly, so must exports. What will America export?” It's a tough question. So perhaps I should opt for discretion over valor and simply hide behind a tautology: In the future, the U.S. will export the goods and services in which we have a comparative advantage! But let me try to venture just a bit beyond the realm of tautology.

For openers, I believe that service offshoring will exacerbate our already-large trade deficit, and that this imbalance will eventually drive down the value of the U.S. dollar. Trade theorists rarely mention nominal exchange rates, and even open-economy macro models typically assume that equilibrium real exchange rates do not change. I beg to differ. I believe that part of the United States' trade problem will be solved by a substantial real (and nominal) depreciation of the dollar, which will restore comparative advantage in places where we otherwise would lose it. The cost, of course, will be some diminution of the American standard of living.

Second, and related, service offshoring is a two-way street. The U.S. will not lose its comparative advantage in all of the impersonal services that become increasingly tradable. I am thinking, for example, of the United States’ strong competitive edge in finance, entertainment, and higher education. While none of them are impervious to foreign competition, Wall Street, Hollywood, and our great universities are not easily replicated abroad. And there are many other examples. 
Third, it is crucial that the United States remain the incubator of new business ideas and the first mover when it comes to providing new goods and services. I like to use television sets as an example. The TV manufacturing industry really started here and at one point employed many workers. But as TV sets became "just a commodity," their production moved offshore to locations with much lower wages. And nowadays, the number of television sets manufactured in the United States is zero. A failure? No, a success. Like the cowboy hero, the leader innovates and moves on.

More important, we need to make sure that such success stories continue to proliferate--not because we prize the job destruction in the sunset industries that we lose, but because we value the job creation in the sunrise industries that we gain, even if those jobs won’t stay here forever. Trying to name concrete examples of future industrial winners is a fool's errand, and I won't go there. Imagine yourself as Thomas Jefferson's chief economic adviser in 1802 (who should have been, but wasn't, Alexander Hamilton). You've just told the president that the share of Americans earning their living on farms will fall from $84 \%$ to $2 \%$ within $150-200$ years--a great prediction. The great man looks worried, and asks: “And what will the other 82\% do?” You couldn’t have answered, but neither could anyone else.

While I'm not foolish enough to try to name the new industrial winners, we all know that many new goods and services will be invented and/or commercialized in the coming decades. As the world's leading nation, the United States must grab the firstmover advantage in a disproportionate share of these. And that, in turn, requires that we remain a hotbed of business creativity and innovation. To accomplish this, basic research, industrial R\&D, creative and aggressive business management, an entrepreneurial 
culture, an active venture capital industry, and the like must all remain integral parts of the American success story. Thus, in short, a large part of the answer to the question, “What will we export in the future?” is: the new stuff.

\section{An offshoring miscellany}

Large-scale offshoring of impersonal service jobs from rich countries to poor countries will have numerous other implications, many of which we cannot even imagine now. But here are a few things that come to mind.

Slower average productivity growth: If, in fact, the U.S. and other rich countries reallocate labor from manufacturing and impersonal service jobs, where there is rapid productivity improvement, to personal service jobs, where there is little or none, these nations' (weighted average) productivity growth rates will decline. Of course, the opposite reallocation will be going on in countries like India and China, boosting their productivity growth rates. This sectoral reallocation is a natural part of the international convergence process. ${ }^{30}$

The U.S. vs. Europe: The U.S. will probably cope with the necessary workplace and educational changes better than Europe, which has been talking much (but doing little) about fixing labor market “rigidities” for at least two decades. Both history and logic suggest that markets, not governments, will play the lead role in effectuating the necessary shift of labor toward personally-delivered services_-and that markets will succeed. But the fluid, flexible American labor market will probably adapt better and faster than European labor markets. On the other hand, the non-English-speaking

\footnotetext{
${ }^{30}$ See, for example, Baumol et al. (1989).
} 
countries of Europe will have less adapting to do because they will face less foreign competition in electronically-delivered services.

China vs. India: Americans, and residents of other English-speaking countries, probably need to start worrying less about competition from China, which is largely in manufactured goods, and more about competition from India, which is mainly in services. Speaking English is a notable source of comparative that seems destined to grow in importance as impersonal services account for an increasing share of international trade. India has it. China does not.

Wage Inequality: Wage disparities between highly-educated and poorly-educated workers have grown alarmingly in the United States and in some other rich countries for decades. This phenomenon is largely blamed on skill-biased technical progress, which is widely expected to continue. But perhaps it will not. I have argued here that the richcountry jobs that are most vulnerable to offshoring, and thus will be under the greatest wage pressure in the future, are not mostly low-end jobs. They are jobs providing impersonal services, some of which now pay very high wages and some of which do not.

Need for new data: Sadly, the national data systems of the U.S. and other industrial countries have not even fully adapted to the First Industrial Revolution yet. Governments all over the industrial world still devote vastly more resources to collecting agricultural data than the small size of that industry merits. So it can hardly be surprising that our data systems have failed to adapt to the Second Industrial Revolution—-the shift to services. Throughout the world, there is far less information on the service sector (which is the majority everywhere) than on manufacturing (which is the minority). The Third Industrial Revolution demands not only that we keep better statistical tabs on 
services, but that we start collecting systematic data on which service jobs are deliverable electronically over long distances and which are not. Needless to say, no one is doing this now. It will be hard even to assess the size and nature of the offshoring problem, much less to do anything constructive about it, in the absence of such data.

Job satisfaction: I close my potpourri on an optimistic note, with a highlyconjectural possible side-effect of the coming shift from manufacturing and impersonal services to personal services. Human beings are social animals who enjoy human contact. For many decades, it looked as if modern economic life was destined to reduce the volume of human contact in the workplace-separating people and isolating them. (Remember Charlie Chaplin in Modern Times?) In future decades, that trend may reverse in the rich countries, as personal services come to predominate more, possibly leading to less alienation and greater average job satisfaction.

\section{A recapitulation}

Let me conclude by summarizing the basic argument as crisply as I can, leaving out all the details and nuances:

- Thanks to electronic communications and globalization, the future is likely to see much more offshoring of impersonal services, that is, services that can be delivered electronically from afar with little or no degradation of quality.

- Thanks to the emergence of China, the former Soviet bloc, and especially India, there will be a lot more workers available to do these jobs. This new expansion of international trade will raise world welfare, and we should not try to stop it with protectionism. 
- Service offshoring may eventually amount to a Third Industrial Revolution, and industrial revolutions have a way of transforming societies. For openers, rich countries will need to shift sizable portions of their workforces out of impersonal services and manufacturing and into personal services-and to train their workforces accordingly.

- That said, the "threat” from offshoring should not be exaggerated. Just as the First Industrial Revolution did not banish agriculture from the rich countries, and the Second Industrial Revolution has not banished manufacturing, the Third Industrial Revolution will not drive all impersonal services off shore. Nor will it lead to mass unemployment. But the necessary adjustments will be large, multi-faceted, and complex. In a word, it's likely to be a big deal.

- The societies of the rich countries seem to be completely unprepared for the coming industrial transformation. Our national data systems, our trade policies, our educational systems, our social welfare programs, our politics, and much else must adapt to the fundamental movement from impersonal to personal service jobs. None of this is happening now.

When I talk to my fellow economists about offshoring, I often feel a bit like Paul Revere sounding the alarm to awaken his slumbering neighbors-except that many of my intellectual neighbors do not appreciate being rousted out of bed. And this time it's not the British who are coming, but the Indians. And they are coming neither by land nor by sea, but electronically. And, by the way, we certainly don't want to fight them off. (So please stay right here; don’t rush off to Lexington or Concord.) 
In particular, we Americans should not blame the Indians for the large adjustment problems that we will have to confront in the coming decades. They are doing exactly what they should be doing--developing their own country by exploiting their comparative advantage and, in the process, making the world as a whole immensely better off. We should shake their hands and wish them well--which is not exactly how the Minutemen greeted the Redcoats. 


\section{References}

Atkinson, Robert D. 2006. “Apocalypse Soon? Why Alan Blinder Gets it Wrong on Offshoring.” Washington, D.C.: The Information Technology and Innovation Foundation, July 6, 2006.

Baumol, William J. 1967. "Macroeconomics of Unbalanced Growth: The Anatomy of Urban Crisis.” American Economic Review 57 (3, June), pp. 415-426.

Baumol, William J., Sue Anne Batey Blackman, and Edward N. Wolff. 1989. Productivity and American Leadership: The Long View. Cambridge, Mass.: MIT Press.

Bhagwati, Jagdish N. 1968. “Distortions and Immiserizing Growth: A Generalization.” Review of Economic Studies 35(4), pp. 481-85.

Bhagwati, Jagdish N. 1997. “A New Epoch?, The New Republic (May 19, 1997), pp. 3641. (Reprinted in his A Stream of Windows: Unsettling Reflections on Trade, Immigration, and Democracy. Cambridge, Mass.: The MIT Press, pp. 3-28.)

Bhagwati, Jagdish, Arvind Panagariya, and T.N. Srinivasan. 2004. "The Muddles over Outsourcing.” Journal of Economic Perspectives 18 (4, Fall), pp. 93-114.

Blinder, Alan S. 2006a. “Offshoring: The Next Industrial Revolution?” Foreign Affairs 85 (2, March-April), pp. 113-28.

Blinder, Alan S. 2006b. “Outsourcing: Bigger Than You Thought.” The American Prospect 17 (11, November), pp. 44-46.

Blinder, Alan S. March 2007. “How Many U.S. Jobs Might Be Offshorable?” CEPS Working Paper No. 142. Princeton University.

Burtless, Gary. 1995. “International Trade and the Rise in Earnings Inequality.” Journal of Economic Literature 23 (June), pp. 800-816.

Davidson, Carl and Steven J. Matusz. 2000. "Globalisation and Labour-Market Adjustment: How Fast and at What Cost?,” Oxford Review of Economic Policy 16 (3, Autumn), pp. 42-56.

Davidson, Carl and Steven J. Matusz. 2006. “Trade Liberalization and Compensation.” International Economic Review 47 (3, August), pp. 723-47.

Freeman, Richard. 2005. "What Really Ails Europe (and America): The Doubling of the Global Workforce.” Washington, D.C.: The Globalist (www.theglobalist.com), June 3.

Gomory, Ralph E. and William J. Baumol. 2000. Global Trade and Conflicting National Interests. Cambridge, Mass.: The MIT Press. 
Grossman, Gene M. and Esteban Rossi-Hansberg. August 2006. “Trading Tasks: A Simple Theory of Offshoring.” Princeton University working paper.

Hymans, Saul and Frank Stafford. 1995. "Divergence, Convergence, and the Gains from Trade,” Review of International Economics 3(1), pp. 118-123.

LaLonde, Robert J. 1995. "The Promise of Public Sector-Sponsored Training Programs.” Journal of Economic Perspectives 9 (2, Spring), pp. 149-168.

Levy, Frank and Kyoung-Hee Yu. March 2006. "Offshoring of Professional Services: Radiology Services from India.” MIT working paper.

Mankiw, N. Gregory and Phillip Swagel. July 2006. “The Politics and Economics of Offshore Outsourcing.” National Bureau of Economic Research, working paper no. 12398.

National Academy of Public Administration. January 2006. Off-Shoring: An Elusive Phenomenon. Washington, D.C.: Academy Project no. 2051-000.

Nordhaus, William D. May 2006. “Baumol’s Diseases: A Macroeconomic Perspective.” National Bureau of Economic Research, working paper no.12218.

Samuelson, Paul A. 2004. "Where Ricardo and Mill Rebut and Confirm Arguments of Mainstream Economists Supporting Globalization.” Journal of Economic Perspectives 18 (3, Summer), pp. 135-146. 